
\title{
$\begin{array}{ll}\text { Research Square } & \text { They should not be considered conclusive, used to inform clinical practice, } \\ \text { or referenced by the media as validated information. }\end{array}$
}

\section{Antimicrobial Effect of Geophila Obvallata (Schumach) Didr. Leaf Extracts Against Some Medically Important Bacteria and Fungi}

Lucky Osafanme Iserhienrhien ( $\sim$ luckcheif@gmail.com )

University of Benin

Okolie Ngozi Paulinus

University of Benin

Etaware Peter Mudiaga

University of Ibadan

\section{Research Article}

Keywords: Geophila obvallata, Ciprofloxacin, Ketoconazole, Antimicrobial, Inhibition zone diameter, Antifungal

Posted Date: November 2nd, 2021

DOI: https://doi.org/10.21203/rs.3.rs-963672/v1

License: (c) (i) This work is licensed under a Creative Commons Attribution 4.0 International License. Read Full License 


\section{Abstract}

Background: The increase in synthetic drug resistance by pathogenic microbes has led to the development of plant-based antimicrobial drugs that are more reliable and non-lethal to human health at increased dosage.

Methods: The antibacterial and antifungal potential of Geophila obvallata extracts were tested on clinical isolates (Staphylococcus aureus, Klebsiella pneumoniae, Pseudomonas aeruginosa, Escherichia coli, Bacillus subtilis, Streptococcus pyogenes, Cryptococcus neoformans, Candida albicans and Aspergillus fumigatus) using standard techniques.

Results: The zones of inhibition were shown to increase with increasing concentrations of the extracts. Inhibition was higher in Gram positive bacteria (9.10 to $31.00 \mathrm{~mm}$ in $40 \mathrm{mg} / \mathrm{mL}$ concentration) than Gram negative bacteria ( 3.50 to $27.00 \mathrm{~mm}$ in $40 \mathrm{mg} / \mathrm{mL}$ concentration), while the fungal isolates had the least zones of inhibition ( 2.83 to $25.00 \mathrm{~mm}$ in $40 \mathrm{mg} / \mathrm{ml}$ concentration). The minimum inhibitory concentrations (MIC) were lowest in the methanol extract than aqueous extract. Simillarly, MIC for bacteria (Bacillus subtilis) and fungi (Aspergillus fumigatus) were 0.3 and $2.0 \mathrm{mg} / \mathrm{mL}$ respectively. Methanol extract had higher antibacterial and antifungal effect than aqueous extract. Ciprofloxacin, used as control for bacteria had the highest inhibitory activity (33.67mm) when compared to that of the highest concentration of plant extracts administered. Also, ketoconazole gave the highest zones of inhibition (32.33mm) on the fungi isolates compared to those of the extracts. The performance of the methanol extract of $40 \mathrm{mg} / \mathrm{mL}$ of Geophila obvallata in the inhibition of Bacillus subtilis was not significantly different from that of Ciprofloxacin.

Conclusion: The findings in this study therefore validate the antimicrobial effect of Geophila obvallata leaf extracts as well as its possible application in medicine.

\section{Introduction}

The increasing occurrence of multi-drug resistant strains of infectious bacteria and fungi is a major threat to public health worldwide. The distribution of these resistant strains in the population has rendered most antibiotics and major last - resort drugs ineffective in combating infections or diseases (Mandal et al., 2009; Bhatia and Narain, 2010). Microbial resistance to antimicrobial agents increases the chance of hospitalization and in most cases death (Winstanley, 1997). In recent times, the indiscriminate use of antibiotics in most developing and developed countries of the world has led to reports of drug resistance to pathogenic microbes in humans (Gupta et al., 2017). As a result of this rapid spread and development of resistance microbial strains, the need for the discovery of novel antimicrobial agents that are effective alternatives to synthetic and hazardous chemical drugs cannot be over-emphasised. This has led to the exploration of plants and plant based products as novel remedies in the treatment of disease (Basualdo et al., 2007; Mandal et al., 2010). Plant based antimicrobials (extracts) have been recognised as valuable alternatives in the treatment of most microbial infections compared to synthetic antibiotics due to their stability, non-lethality and efficacy (Iwu et al., 1999; Alam et al., 2009). Currently, more than $30 \%$ of the antimicrobial agents produced in modern pharmacology are obtained directly or indirectly from plants and their extracts (Murugesan et al., 2011). The World Health Organization (WHO) has affirmed medicinal plants as the best source of drugs (WHO, 2002).

Geophila obvallata (GO) (Schumach.) Didr. is a perennial, carpet forming, creeping herb usually wooden at the base (Reeve, 1997). It possesses broadly ovate, dark green, hairless leaves and roots 6-9 meters long. It is mostly found in shady places under the cover of trees with few white flowered clusters (Flora et al., 2010). This plant species belongs to the taxonomic family Rubiaceae (Robbrecht and Manen, 2006) where there are over twenty (20) different species of which GO is the most commonly found in West tropical rainforests (Owu et al., 2012). Previous studies have shown that this plant possesses antimicrobial potentials. This is as a result of the rich secondary metabolites such as tannins, alkaloids, phenols, and flavonoids biosynthesised by the plant (Iserhienrhien and Okolie, 2018). In West tropical Africa (Nigeria), the leaves of this neglected and greatly under- exploited plant has an array of health benefits (folklore) translating from its use by the locals in the treatment of sores from guinea worm infections, diarrhea, infertility and hypertension. The plant leaves have been screened for phytochemicals and reported to possess antioxidant activity (Iserhienrhien and Okolie, 2018). Previous toxicological studies by Iserhienrhien and Okolie, (2020) revealed that the hydro-methanolic extract of this plant is non-lethal at a dose of $100 \mathrm{mg} / \mathrm{kg}$. Also, the antifungal (Portillo et al., 2001), antibacterial (Rao et al., 2017) and anticholinesterase (Dash and Sahoo, 2017) effects have also been studied in the leaves of a similar genus, Geophila repens. However, there is paucity in scientific data regarding the efficacy of the plant as an antimicrobial agent. Considering the vast potential of this plant, this study investigated the antimicrobial effect of Geophila obvallata (Schumach) Didr. leaf extracts against some medically important bacteria and fungi.

\section{Material And Methods}

\section{Plant collection}

Geophila obvallata leaves were obtained from the Gelegele forest after appropriate permission was given by the community healer and identified by Dr. H.A. Akinnibosun (taxonomist), at the Department of life science Herbarium, University of Benin, Nigeria, with voucher number UBHa 0312 assigned to it.

\section{Plant extraction}

The plant leaves were manually detached, cleaned and air-dried for 30 days. Dried plant parts were grinded using an electric mill GM 150 (Retch, Germany) until a smooth texture was obtained, and was later weighed and packaged. The pulverized leaves (200g) were extracted in the soxhlet extractor using methanol (70\%) (1:10 w/v) (Iserhienrien et al., 2018) followed by homogenization and continuous agitation for 3 days. Whatman's filter paper (No. 1) was used to separate the homogenate from the filtrate, after which it was concentrated using a rotary vacuum evaporator R-250V (Buchi, UK) until the methanol evaporated at $40^{\circ} \mathrm{C}$ (Edeoga et al., 2005). The same procedure was adopted for the aqueous extract. Both extracts were stored at $4^{\circ} \mathrm{C}$ for analysis. The methanol and aqueous yield (\%) were 4.85 and 2.57 respectively, calculated using the formula below: 


\section{Preliminary phytochemical profiling}

The bioactive constituents present in the methanol and aqueous extracts of Geophila obvallata were previously screened for flavonoids, polyphenols, alkaloids, tannins, saponins, steroids, terpenoids and cardiac glycosides (Iserhienrhien and Okolie, 2018), according to the methods described by Sofowora, (1993).

\section{Microbial culture}

A total of 9 clinical isolates were obtained from stock cultures after appropriate permission was sought from the Department of Pharmaceutical Microbiology laboratory, Faculty of Pharmacy, University of Benin, Nigeria. The referenced microorganisms include: S. aureus, K. pneumoniae, P. aeruginosa, E. coli, B. subtilis, $S$. pyogenes, $C$. neoformans, $C$. albicans and $A$. fumigatus. Prior to use, the test microorganisms were authenticated and sub-cultured from stock into sterile nutrient broth (for bacteria) and Sabouraud Dextrose broth (for fungi) and incubated overnight at $38^{\circ} \mathrm{C}$ for $24 \mathrm{hours} \mathrm{for} \mathrm{bacteria} \mathrm{and} \mathrm{at} \mathrm{room}$ temperature $\left(25 \pm 2^{\circ} \mathrm{C}\right)$ for 72 hours for fungi. After incubation, overnight broth culture was adjusted to $0.5 \mathrm{McFarland}$ standard to give an inoculum size of approximately $1.5 \times 10^{8} \mathrm{cfu} / \mathrm{mL}$ and a further one in hundred serial dilution (1:100) using normal saline solution to yield approximately $10^{6} \mathrm{cfu} / \mathrm{mL}$.

\section{Antimicrobial assay of plant extracts}

Antimicrobial susceptibility test was carried out using agar-well diffusion method (Vinothkumar et al., 2010). Wells of 7 mm in diameter were made into previously seeded Mueller Hinton / Sabouraud agar plates using a flamed (sterile) cork borer. Prior to seeding, the turbidity of the overnight broth culture of each isolates were adjusted to match $0.5 \mathrm{McF}$ arland turbidity standard and diluted (1:100) to give approximately $1 \times 10^{6} \mathrm{cfu} / \mathrm{mL}$ microbial suspension. Sterile swab sticks were then dipped into the standardized microbial suspension and gently streaked on the surface of the agar plates in even strokes to obtain a uniform growth pattern across the entire surface of the plate. This was achieved by rotating the plate 90 degrees followed by 45 degrees with continuous streaking, and finally by streaking round the diameter of the agar. The $7 \mathrm{~mm}$ wells were filled with different volumes of the stock concentration of the extracts corresponding to $40,30,20$ and $10 \mathrm{mg} / \mathrm{mL}$ concentrations. The same quantity of sterilized distill water, standard drugs $(1 \mu \mathrm{g} / \mathrm{mL}$ of Ciprofloxacin for bacteria plates and $10 \mu \mathrm{g} / \mathrm{mL}$ of Ketoconazole for fungal plates) served as controls setup for the experiment. The plates were left to stand for 1 hour on a work-bench to allow diffusion of the extracts before incubating bacterial plates overnight at $37^{\circ} \mathrm{C}$ and the fungal plates at room temperature $\left(25 \pm 2{ }^{\circ} \mathrm{C}\right)$ for 72 hours. The diameter of clear zone was observed and measured in $\mathrm{mm}$ (millimeters). The experiments including controls were done in triplicates and the mean zones of inhibitions calculated.

\section{GC-MS analysis of methanol extract}

The analysis was done with GCMS-QP2010SE (Shimadzu, Japan). Helium served as carrier gas at a column flow rate of 3.22mL/min with a split ratio of 5:1. $1 \mu \mathrm{l}$ of sample was injected into the column at an injection temperature of $250.00^{\circ} \mathrm{C}$ and detection temperature was $290{ }^{\circ} \mathrm{C}$. The oven starts at $60{ }^{\circ} \mathrm{C}$ while the hold time is for $2 \mathrm{mins}$, this is maintained at $10^{\circ} \mathrm{C} / \mathrm{min}$ to $290^{\circ} \mathrm{C}$ without holding. Total running time was 21 mins. The detector was a flame ionization detector (FID). Detected peaks were compared with NIST 11s, library to verify the names and molecular weights of the samples constituents.

\section{Data analyses}

Data collected during this study were analyzed using MINITAB 16 and represented as mean \pm standard deviation. Fishers Pairwise Comparison (FPC) of ANOVA at a significance level of $P<0.05$ was used to test the variability in susceptibility of the microorganisms towards the extractives.

\section{Results}

The in vitro experiment conducted showed that the best antimicrobial effect on K. pneumonia, P. aeruginosa, E. coli, S. aureus and S. pyogenes were seen in the methanol ( 30 and $40 \mathrm{mg} / \mathrm{mL}$ ) extract group when compared with the aqueous extract group. The zones of inhibition on culture plate of the isolates at 30 and $40 \mathrm{mg} / \mathrm{mL}$ of the methanol extract were measured as 25.67 and $27.00 \mathrm{~mm}$, respectively for $K$. pneumonia, 21.33 and $24.00 \mathrm{~mm}$, respectively for $P$. aeruginosa, 25.67 and $26.00 \mathrm{~mm}$, respectively for E. coli, 24.33 and $27.33 \mathrm{~mm}$, respectively for $S$. aureus, 27.67 and $29.33 \mathrm{~mm}$, respectively for S. pyogenes (Table 1). Indicating that both concentrations of the methanol extracts of Geophila obvallata performed very well in limiting the growth and metabolic activities of the isolates compared to the aqueous extract and the control setup for the experiment $\left(\mathrm{DH}_{2} \mathrm{O}\right)$. Ciprofloxacin (CIP) a synthetic drug, performed better than all other groups (Table 1). However, the performance of the methanol extract at $40 \mathrm{mg} / \mathrm{mL}$ of Geophila obvallata in the inhibition of the microbe $B$. subtilis was not significantly different $(P>0.05)$ from that of the synthetic drug Ciprofloxacin. 
Table 1

Inhibition zone diameter of Geophila obvallata extracts against test bacterial isolates

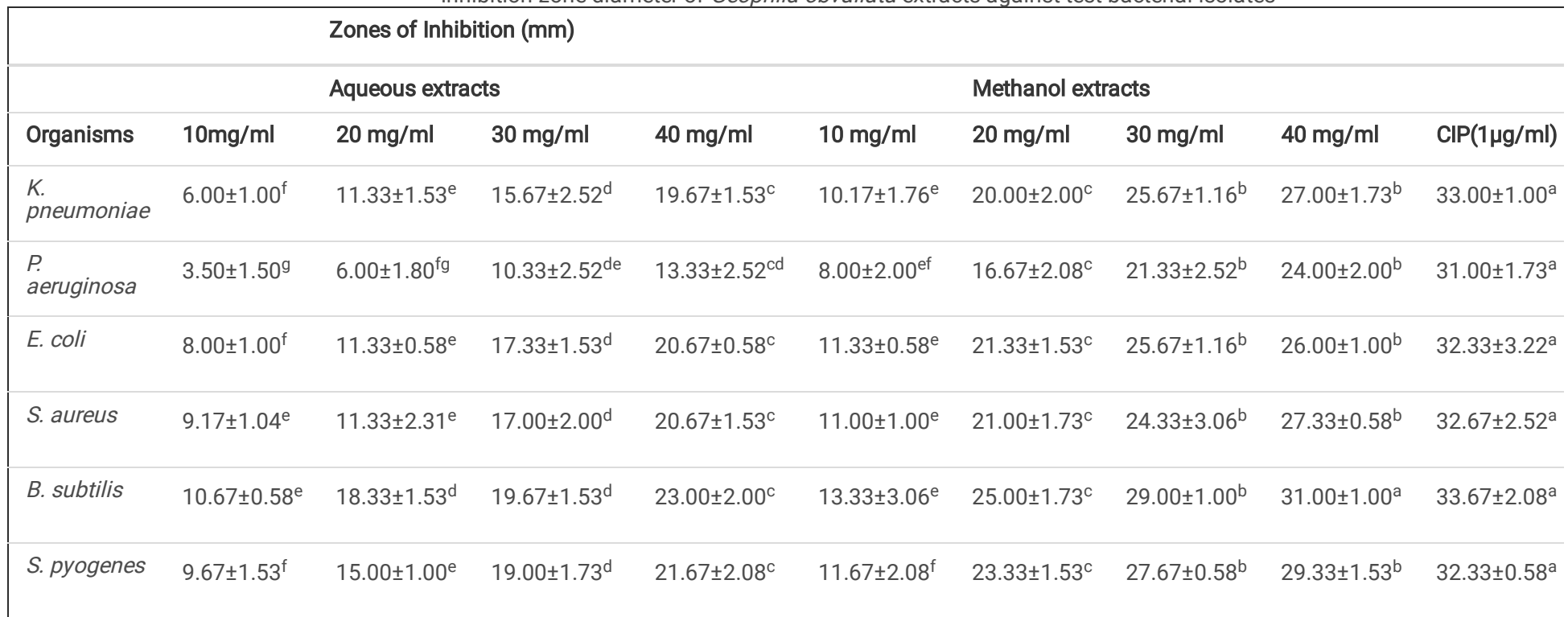

Means with the same alphabets across the row are not significantly different $(\mathrm{P}>0.05)$ using Fishers Pairwise Comparison (FPC). Data collected are represented as mean \pm standard deviation

Table 2

Inhibition zone diameter of Geophila obvallata extracts against test fungal isolates

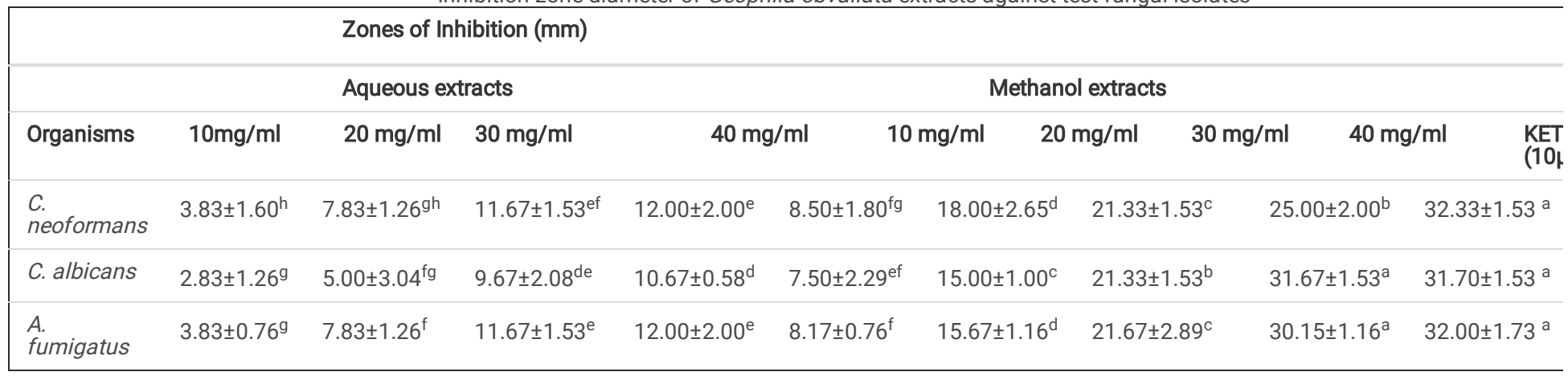

Means with the same alphabets across the row are not significantly different $(\mathrm{P}>0.05)$ using Fishers Pairwise Comparison (FPC). Data collected are represented as mean \pm standard deviation

The methanol extract of Geophila obvallata had the best antifungal effect on all the fungal isolates (C. neoformans, $C$. albicans, and $A$. fumigatus), especially at $40 \mathrm{mg} / \mathrm{mL}$ of the administered treatment when compared with other groups. The group treated with $40 \mathrm{mg} / \mathrm{mL}$ methanol extract significantly $(\mathrm{P}<0.05)$ inhibited the radial mycelial growth of $C$. albicans and $A$. fumigatus when compared with the aqueous extract group. Also, the group treated with $40 \mathrm{mg} / \mathrm{mL}$ of the methanol extract produced similar effects on the pathogen $C$. albicans (31.67 mm clear zone of inhibition) and $A$. fumigatus (30.15 mm clear zone of inhibition) just like that of the synthetic drug (Ketoconazole), other treatment concentrations and water extracted botanicals had appreciable control of the fungal isolates (Table 2). 
Table 3

Minimum inhibitory concentrations (MICs) of the methanol extract against the test organisms

\begin{tabular}{|c|c|c|c|c|c|c|c|c|c|c|}
\hline \multirow[t]{2}{*}{ Organisms } & \multicolumn{10}{|c|}{ Concentrations (mg/ml) } \\
\hline & 10 & 8 & 6 & 4 & 2 & 0.9 & 0.7 & 0.5 & 0.3 & 0.1 \\
\hline K. pneumoniae & - & - & - & - & + & + & + & + & + & + \\
\hline$P$. aeruginosa & - & - & - & + & + & + & + & + & + & + \\
\hline E. coli & - & - & - & - & - & - & + & + & + & + \\
\hline S. aureus & - & - & - & - & - & + & + & + & + & + \\
\hline B. subtilis & - & - & - & - & - & - & - & - & - & + \\
\hline S. pyogenes & - & - & - & - & - & - & - & + & + & + \\
\hline C. neoformans & - & - & - & - & + & + & + & + & + & + \\
\hline C. albicans & - & - & - & + & + & + & + & + & + & + \\
\hline A. fumigatus & - & - & - & - & - & + & + & + & + & + \\
\hline
\end{tabular}

Table 4

Minimum inhibitory concentrations (MICs) of the aqueous extract against the test organisms

\begin{tabular}{|c|c|c|c|c|c|c|c|c|c|c|}
\hline \multirow[t]{2}{*}{ Organisms } & \multicolumn{10}{|c|}{ Concentrations (mg/ml) } \\
\hline & 10 & 8 & 6 & 4 & 2 & 0.9 & 0.7 & 0.5 & 0.3 & 0.1 \\
\hline K. pneumoniae & - & - & + & + & + & + & + & + & + & + \\
\hline$P$. aeruginosa & - & + & + & + & + & + & + & + & + & + \\
\hline E. coli & - & - & - & + & + & + & + & + & + & + \\
\hline S. aureus & - & - & - & - & + & + & + & + & + & + \\
\hline B. subtilis & - & - & - & - & - & - & + & + & + & + \\
\hline S. pyogenes & - & - & - & - & - & + & + & + & + & + \\
\hline C. neoformans & - & - & + & + & + & + & + & + & + & + \\
\hline C. albicans & - & + & + & + & + & + & + & + & + & + \\
\hline A. fumigatus & - & - & - & + & + & + & + & + & + & + \\
\hline
\end{tabular}

The results displayed in Tables 3 and 4 showed that the methanol extract had the best activity on 5 out of the 9 clinical isolates [S. aureus, K. pneumoniae, $P$. aeruginosa, E. coli, B. subtilis, S. pyogenes, C. neoformans, C. albicans and $A$. fumigatus] with MICs ranging from $0.3-2 \mathrm{mg} / \mathrm{mL} \mathrm{compared}$ to the aqueous extract. The most promising antibacterial effect was observed against gram-positive bacteria [S. aureus, $B$. subtilis and $S$. pyogenes] compared with the gramnegatives. The methanol extract demonstrated the highest antibacterial activity against $B$. subtilis with a MIC of $0.3 \mathrm{mg} / \mathrm{ml}$ and the best antifungal activity against $A$. fumigates with a MIC of $2 \mathrm{mg} / \mathrm{mL}$.

The GC-MS results revealed twenty-six peaks of phytocompounds present in the methanol extract. Some of these include: Phenols (0.12\%), Oxalic acid, isobutyl nonyl ester (0.08\%), N-(1H-Tetrazol-5-yl) benzamide (0.08\%), cis-Undec-4-enal, Hexadecanoic acid, methyl ester (0.35\%), 1-Heptadec-1-ynyl-cyclopentanol (0.06\%), Undecanoic acid, 10-methyl-, methyl ester (0.21\%), Hydrofol Acid, 12-methyl-, methyl ester (0.31\%), 8-Hexadecenal, 14-methyl-, (Z)-(0.07\%), Dimethoxybicyclo (0.98\%), 8-Hexadecenal, 14-methyl-, (Z)- (0.21\%), 11Oxa-dispiro, methyl ester, (Z)- (0.36\%), Hexadecanoic acid, methyl ester (11.06\%), 9,12-Octadecadienoic acid (Z,Z)-, methyl ester (\%),11Octadecenoic acid, methyl ester (13.16\%), Methyl stearate (31.49\%), cis-Vaccenic acid (4.18\%), Oleic Acid (2.87\%), 9,12-

Octadecadienoic acid (Z,Z)- (4.18\%), methyl ester (2.87\%)(, 7-Hexadecenoic acid (2.45\%), methyl ester, (Z)- (2.17\%), Methyl 9eicosenoate (3.25\%), N-(1H-Tetraazol-5-yl)benzamide, (2.16\%), cis-9-Hexadecenal (2.16\%), Methyl 16-hydroxy-hexadecanoate (3.31\%)respectively (Figure 1; Table 5). Table 5 shows the bioactivities of the reported phyto-compounds.

Table 5 Bioactivities of the reported phyto-compounds in the methanol extract of Geophila obvallata 


\begin{tabular}{|c|c|c|c|}
\hline $\mathrm{S} / \mathrm{N}$ & Compounds & Bio-activity & References \\
\hline 1 & Phenol & Antioxidant, Anticancer, Antimicrobial & (Bakkalbasi and Mentesz, 2008) \\
\hline 2 & Oxalic acid, isobutyl nonyl ester & - & - \\
\hline 3 & $\mathrm{~N}$-(1H-Tetrazol-5-yl)benzamide & Antipsychotic action & (Roessner and Sabine, 2011) \\
\hline 4 & cis-Undec-4-enal & - & - \\
\hline 5 & Undecanoic acid, 10-methyl-, methyl ester & Biomarker for facultative aerobes & (Maribel et al., 2007) \\
\hline 6 & 1-Heptadec-1-ynyl-cyclopentanol & Antihelminthic, Ophthalmic action & (Macedo et al., 2019) \\
\hline 7 & Hydrofol Acid & Antimicrobial, antifungal & (Carson et al., 2006) \\
\hline 8 & 8-Hexadecenal, 14-methyl-, (Z)- & Anticardiovascular, Antiviral & ‘ \\
\hline 9 & 2,4-Undecadienol & Fragrance agent & ‘ \\
\hline 10 & 8-Hexadecenal, 14-methyl-, (Z)- & Anticardiovascular & ' \\
\hline 11 & Dimethoxybicyclo & Antimicrobial, Antiinflammatory & (Rajeswari et al., 2012) \\
\hline 12 & 11-0xa-dispiro & Antimicrobial, Antioxidant & (Rajeswari et al., 2012) \\
\hline 13 & 7-Hexadecenoic acid, methyl ester, (Z)- & Antioxidant, hypocholesterolemic, nematicide & (Moonjit and Himaja, 2014) \\
\hline 14 & N-(1H-Tetraazol-5-yl)benzamide & Antioxidant, antimicrobial & (Moonjit and Himaja. 2014) \\
\hline 15 & n-Hexadecanoic acid & Antioxidant hypocholesterolemic, nematicide & (Moonjit and Himaja, 2014) \\
\hline 16 & 9,12-Octadecadienoic acid (Z,Z)-, methyl ester & Anticardiovascular & ‘ \\
\hline 17 & 11-Octadecenoic acid, methyl ester & Anticardiovascular & ‘ \\
\hline 18 & Methyl stearate & - & (Ann et al., 2013) \\
\hline 19 & cis-Vaccenic acid & Anticancer & (Sales-Campo et al., 2013) \\
\hline 20 & Oleic Acid & Anticardiovascular, Anti-inflammatory & (Sales-Campo et al., 2013) \\
\hline 21 & 9,12-Octadecadienoic acid (Z,Z)-, methyl ester & Lubricant, Antiandrogenic and Flavor & (Moonjit and Himaja, 2014) \\
\hline 22 & 7-Hexadecenoic acid, methyl ester, (Z)- & Antiandrogenic and Flavor & (Moonjit and Himaja, 2014) \\
\hline 23 & Methyl 9-eicosenoate & - & ‘ \\
\hline 24 & Methyl 18-methylnonadecanoate & - & - \\
\hline 25 & cis-9-Hexadecenal & Anti-inflammatory & (Ann et al., 2013) \\
\hline 26 & Methyl 16-hydroxy-hexadecanoate & Antioxidant & (Sales-Campo et al., 2013) \\
\hline
\end{tabular}

\section{Discussion}

The rational use of medicinal plants in tackling multi-drug resistant strains of infectious bacteria and fungi is becoming invaluable. Currently, there are rising trends in the use of natural products (extractives) of plants as indispensable tools in combating the emergence of microbial resistance. The various bioactive compounds inherent in these plants can deploy numerous mechanisms in minimizing antimicrobial resistance thereby increasing their antibacterial or antifungal efficacy (Galeane et al., 2017).

Assessing the antibacterial and antifungal activities of the Geophila obvallata leaf extracts employed in this study suggests its potential use in the management of patients with multi-drug resistance to pathogenic microbes. The preliminary qualitative and quantitative phytochemical screening of the methanol and aqueous leaf extracts of Geophila obvallata revealed the presence of alkaloids, cardiac glycosides, flavonoids, phenols, saponins, reducing sugars, steroids, tannins and terpenoids (Iserhienrhien and Okolie, 2018). These secondary metabolites are well recognised for their antioxidant, antifungal and antibacterial effects in line with previous findings from other studies (Tan et al., 2008; Bianco et al., 2015; Kouadri, 2018) and have been considered as a treatment regimen for numerous disease conditions.

In this study, the crude aqueous and methanol extracts of Geophila obvallata showed appreciable inhibitory activity against both gram negative bacteria ( $K$. pneumonia, P. aeruginosa, E. coli) and gram positive bacteria ( $S$. aureus and $S$. pyogenes, $B$. subtilis) especially at higher doses. However, the methanol extracts at a dose of $(40 \mathrm{mg} / \mathrm{mL})$ showed the best growth inhibitory performance, especially against the gram positive microbe $B$. subtilis, which was not significantly different from that of the control (Ciprofloxacin). The antibacterial effect highlighted in the crude methanol extract may be due to (1) the ability of the methanol solvent to permeate the cell walls of the plant thereby liberating bioactive constituents in the leaf such as flavonoids and polyphenolic compounds with antibacterial properties (Mohammed and Omer, 2015), (2) a synergistic effect of the secondary metabolites present in the milieu at that dosage (Dowe et al., 2016). This is in line with the findings of Ho et al. (2010) and Vijayan et al. (2013) that had similar results when they determined the antimicrobial effects of Orthosiphon stamineus methanol leaf extract. Also, it was generally observed that the gram positive bacteria were more susceptible to the inhibitory action of the methanol extract than the gram-negatives. This is probably due to the presence of inhibitory lipopolysaccharide components in the 
mycobacterial cell wall of the gram negatives, which limit the concentration and permeability of antibacterial agents. This finding correlates with the report of Zeinab et al. (2020), that gram-positive bacteria are usually more susceptible to antimicrobial agents. According to the findings of Kumar et al. (2011), Gram negative bacteria are less susceptible to antimicrobial agents than Gram positives, as a result of the phospholipidic composition of their bacterial membrane with an exclusion limit of $600 \mathrm{Da}$.

Simillarly, the methanol extract also showed significant growth inhibitory properties against the radial mycelia growth of fungal isolates ( $C$. neoformans, $C$. albicans, and A. fumigatus) especially at higher doses $(40 \mathrm{mg} / \mathrm{mL})$ compared to the aqueous extract. Also, the group treated with $40 \mathrm{mg} / \mathrm{mL}$ of the $\mathrm{methanol}$ extract produced similar effects like the synthetic drug (Ketoconazole) on the pathogens $C$. albicans (31.67 mm clear zone of inhibition) and $A$. fumigatus (30.15 mm clear zone of inhibition). This is in correspondence with previously published results by Neharkar and Laware, (2013) revealing the inhibitory effects of methanol extracts on fungal activity. This can also be linked to the high concentration of alkaloids reported in earlier research by Iserhienrhien and Okolie, (2018) on the qualitative phytochemicals present in Geophila obvallata methanol leaf extracts.

The MIC test was used to determine the lowest concentration of the extract that would inhibit the visible growth of the clinical isolates after overnight incubation (Fabry et al., 1998). The crude aqueous and methanol extract both showed significant activity against gram-positive and gram-negative clinical isolates with MIC values ranging from $0.3 \mathrm{mg} / \mathrm{mL}$ to $10.00 \mathrm{mg} / \mathrm{mL}$. However, the methanol extract had the best activity on 5 out of the 9 clinical isolates [S. aureus, E. coli, B. subtilis, S. pyogenes and A. fumigatus] with MICs ranging from $0.3-2 \mathrm{mg} / \mathrm{mL}$ compared to the aqueous extract. The most promising antimicrobial effect was observed against gram-positive bacteria [S. aureus, B. subtilis and $S$. pyogenes] compared with the gram-negatives. The methanol extract demonstrated the highest antibacterial activity against $B$. subtilis with a MIC of $0.3 \mathrm{mg} / \mathrm{mL}$ and the best antifungal activity against $A$. fumigatus with a MIC of $2 \mathrm{mg} / \mathrm{mL}$. Potent antimicrobial agents are known to possess MIC values equal to or lower than $0.50 \mathrm{mg} / \mathrm{ml}$ (Sartoratto et al., 2004). This is a clear indication of exceptional antimicrobial activity (Duarte et al., 2005) and is in line with earlier antimicrobial susceptibility tests (agar-well diffusion method) carried out in this study. The differences in bacterial vulnerability observed in this study are in agreement with previous findings (Wink, 2012) and could be due to (1) diversity in microbial resistance and (2) phytochemical constituents (tannins, alkaloids, terpenoids and flavonoids) present in the active methanol extract with a broad spectrum of antimicrobial action.

The GC-MS chromatogram showed twenty-six peaks of phytocompounds present in the methanol extract with known biological activities while the others have not been linked to any known biological function. The mass spectra of these compounds were matched with the NIST database which helped to elucidate the corresponding peaks. Some of the bioactive compounds found in the extract and their roles according to literature include: phenols which are reported to possess antioxidant, anticancer and antimicrobial effects (Bakkalbasi and Mentesz, 2008), N-(1H-Tetrazol-5-yl) benzamide which possess antipsychotic and anxiolytic action (Roessner and Sabine, 2011), Hydrofol Acid and 11-Oxa-dispiro, possess antioxidant, hypocholesterolemic effects (Moonjit and Himaja, 2014) while Dimethoxybicyclo is known for its antihelminthic, antimicrobial and ophthalmic action (Macedo et al., 2019).

In conclusion, the crude aqueous and methanol leaf extracts of Geophila obvallata showed exceptional concentration-dependent antibacterial and antifungal activity against selected clinical isolates. However, the methanol extract at a dose of $40 \mathrm{mg} / \mathrm{mL}$ showed the best antimicrobial effect against the tested isolates. These findings confirm the antimicrobial potency of the plant extract and give credence to the orthodox use of the medicinal plant as a suitable alternative to synthetic antimicrobial agents.

\section{Declarations}

Supplementary Information: The online version contains supplementary material available at https://doi.org/10.9734/ajrb\%2F2018\%2Fv3i229823

Ethics approval and consent to participate: The experimental protocol and methods were performed in accordance with the relevant guidelines and regulations.

Consent for publication: Not applicable.

Availability of data and materials: The datasets supporting the conclusions of this article are included within the article and its additional file.

Competing interests: The authors declare that they have no competing interests.

Funding: There was no funding.

Authors' contributions: Okolie Ngozi participated in the conception, design of the study, data analysis and drafted the manuscript. Iserhienrhien Lucky carried out the experiments and data analysis. Etaware Mudiaga assisted with the data analysis and helped to draft the manuscript. All authors read and approved the final manuscript.

Acknowledgments: We would like to thank Prof. Akpe Romanus for his support and practical guidiance during this project. We also appreciate Mr. Dowe for his contributions during the study design and laboratory work. Authors declare no conflict of interest.

\section{References}

1. Aiyelaagbe, O.O., P.M., \& Osamudiamen, P.M., (2009). Phytochemical screening for active compounds in Mangifera indica leaves from Ibadan, Oyo State. Plant Scientific Research 2, 11-13. https://medwelljournals.com/abstract/?doi=psres.2009.11.13

2. Alam, M.T., Karim, M.M., \& Khan, S.N. (2009). Antibacterial activity of different organic extracts of Achyranthes aspera and Cassia alata. Journal of Scientific Research, 1, 393-398. https://doi.org/10.3329/jsr.v1i2.2298

Page $7 / 10$ 
3. Ann, S., Micheal, F., \& Penny, E. (2013). The role of diet in CV disease. 3rd ed; Pennsylvania state university, University Park, Pennsylvania. 541-550. https://doi.org/10.1161/CIR.0000000000000510

4. Bakkalbasi, E., \& Mentesz, A.N. (2008). Food ellagitannins. Occurrence, effects of processing and storage. Critical Reviews in Food Science and Nutrition, 49(3), 283-298. https://doi.org/10.1080/10408390802064404

5. Basualdo, C., Sgroy, V., Finola, M.S., \& Juam, M. (2007). Comparison of the antibacterial activity of honey from different provenance against bacteria usually isolated from skin wounds. Veterinary Microbiology, 124, 375-381. DOI: 10.1016/j.vetmic.2007.04.039

6. Bhatia, R., \& Narain, J. P. (2010). "The growing challenge of antimicrobial resistance in the South-East Asia Region - are we losing the battle?" Indian Journal of Medical Research, 132 (5), 482-486. https://dx.doi.org/10.4103\%2F0971-5916.73313

7. Bianco, É.M., Krug, J.L., Zimath, P.L., Kroger, A., Paganelli, C.J., \& Boeder, A.M. (2015). Antimicrobial (including antimollicutes), antioxidant and anticholinesterase activities of Brazilian and Spanish marine organisms - evaluation of extracts and pure compounds. Brazilian Journal of Pharmacognosy. 25(6), 668-76. https://doi.org/10.1186/s12906-020-03183-0

8. Carson, C.F., Hammer, K.A., \& Riley, T.V. (2006). Melaleuca alternifolia (tea tree) oil: a review of antimicrobial and other medicinal properties. Clinical Microbiology Reviews, 19(1), 50-62. https://dx.doi.org/10.1128\%2FCMR.19.1.50-62.2006

9. Dash, U.C., \& Sahoo, A.K. In vitro antioxidant assessment and a rapid HPTLC bioautographic method for the detection of anticholinesterase inhibitory activity of Geophila repens. Journal of Integrated Medicine, 15(3), 231-241. https://doi.org/10.1016/S2095-4964(17)60326-1

10. Dowe, E., Ahonkhai, I., Ayinde, B.A. \& Uwumarongie, H.O. (2016). Phytochemical and antimicrobial evaluation of the methanol stem extract and fraction of Massularia acuminata G. Don (Rubiaceae) against isolated odontopathogens. Ewemen Journal of Microbial Research, 2(1), 13-21.

11. Duarte, M.C.T., Figueira, G.M., Sartoratto, A., Rehder, V.L.G., \& Delarmelina, C. (2005). Anti-Candida activity of Brazilian medicinal plants. Journal of Ethnopharmacology, 97, 305-11. 21. https://doi.org/10.1016/j.jep.2004.11.016

12. Edeoga, H.O., Okwu, D.E., \& Mbaebie, B.O., (2005). Phytochemical constituents of some Nigerian medicinal plants. African Journal of Biotechnology 4 , 685-688. http://dx.doi.org/10.5897/AJB200 5.000-3127

13. Fabry, W., Okemo, P.O., \& Ansorg, R. (1998). Antibacterial activity of east African medicinal plants. Journal of Ethnopharmacology, 60, 79-84. https://doi.org/10.1016/s0378-8741(97)00128-1

14. Flora, S., Mittal, M., Gupta, R., \& Pant, S. (2010). Arsenic Toxicity: Biochemical Effects, Mechanism of Action and strategies for the prevention and treatment by Chelating Agents and Herbal Extracts. India, I. K. International Publishing House Put. Ltd. pp. 1-17.

15. Galeane, M.C., Martins, C.H.G., Massuco, J., Bauab, T.M., \& Sacramento, L.V.S. (2017). Phytochemical screening of Azadirachta indica A. Juss for antimicrobial activity. African Journal of Microbiology Research, 11(4), 117-22. https://doi.org/10.5897/AJMR2016.8337

16. Gupta, P.D. \& Birdi, T.J. (2017). Development of botanicals to combat antibiotic resistance. Journal of Ayurveda and Integrated Medicine, 8(4), $266-75$. https://doi.org/10.1016/j.jaim.2017.05.004

17. Ho, C.H., Noryati, I., Sulaiman, S.F., \& Rosma, A. (2010). In vitro antibacterial and antioxidant activities of Orthosiphon stamineus Benth. extracts against food-borne bacteria. Food Chemistry, 122, 1168-1172. ISSN: 0308-8146

18. Iserhienrhien, L.O. \& Okolie, N.P. (2018). Phytochemical Screening and in vitro Antioxidant Properties of Methanol and Aqueous Leaf Extracts of Geophila obvallata, Asian Journal of Research in Biochemistry, 3(2), 1-11.DOI: 10.9734/AJRB/2018/45052

19. Iserhienrhien, L.O. \& Okolie, N.P. (2020). Acute and sub-acute toxicity profile of methanol leaf extract of Geophila obvallata on renal and hepatic indices in Wistar rats Cogent Food and Agriculture, 6, 1-13. https://doi.org/10.1080/23311932.2020.1794240

20. Iserhienrhien, L.O., Agatemor U.M., Idakwoji, P.A., Nweje- Anyalowu, P.C., Onugwu, E.O. (2018). Anti-ulcerogenic Activity of a Polyherbal Formulation (EXRHF) on Experimental Ulcer Models. International Journal of Advanced Research in Biological Sciences, 5(10), 147-156. DOI: http://dx.doi.org/10.22192/ijarbs.2018.05.10.015

21. Iwu, M. W., Duncan, A. R. \& Okunji, C.O. (1999). "New antimicrobials of plant origin in. Perspectives on new crops and new uses," in Plant Breeding Reviews, 4th Ed., J Alexandria, Virginia, Janick, ASHS Press,

22. Kouadri, F. (2018). In vitro antibacterial and antifungal activities of the Saudi Lawsonia inermis extracts against some nosocomial infection pathogens. Journal of Pure and Applied Microbiology, 12(2), 281-6. http://dx.doi.org/10.22207/JPAM.12.1.33

23. Kumar, P., Bhatt, R. P., Singh, L., Sati, O. P., Khan, A., \& Ahmad, A. (2011). Antimicrobial activities of essential oil and methanol extract of Coriaria nepalensis. Natural Product Research, 25(11), 1074-1081. http://www.tandfonline.com/loi/gnpl20

24. Macedo, T.F., lara, T.F., Lorena, M.B., de Oliveira, W.B., \& Pinheiro André, J. (2019). Anthelmintic effect of Cymbopogon citratus essential oil and its nanoemulsion on sheep gastrointestinal nematodes. Revista Brasiliera de Parasitologia, 28, 3-16. https://doi.org/10.1590/S1984-29612019065

25. Mandal, S., Deb Mandal, M., \& Pal, N.K. (2010). Synergistic anti-Staphylococcus aureus activity of amoxicillin in combination with Emblica officinalis and Nymphae odorata extracts. Asian Pacific Journal of Tropical Medicine, 3, 711-714. https://doi.org/10.1016/S1995-7645(10)60171-X

26. Mandal, S., Pal, N.K., Chowdhury, I.H., \& Deb Mandal, M. (2009). Antibacterial activity of ciprofloxacin and trimethoprim, alone and in combination, against Vibrio cholerae 01 biotype El Tor serotype Ogawa isolates. Polish Journal of Microbiology, 58, 57-60. PMID: 19469287.

27. Maribel, Q., Buitron, G., \& Lopez-Martin, L.M. (2007). The use of fatty acid methyl esters as biomarkers to determine aerobic systems.FEMS Microbiology Letters 266(1), 75-82. https://doi.org/10.1111/j.1574-6968.2006.00509.x

28. Mohammed, H.A., \& Omer, A.F.A. (2015). Antibacterial activity of Azadirachta indica (Neem) leaf extract against bacterial pathogens in Sudan. American Journal of Research Communications, 3(5), 246-51.

29. Moonjit, D., \& Himaja, M. (2014). Phytochemical Screening, GC-MS Analysis and Biological Activities of Ipomoea Eriocarpa Leaf Extracts. International Journal of Pharmaceutical Sciences, 6(4), 592-594. 
30. Murugesan, S., Pannerselvam, A., \& Tangavelou, A.C. (2011). Phytochemical screening and antimicrobial activity of the leaves of Memecylon umbellatum burm. F. Journal of Applied Pharmaceutical Science, 1, 42-45.

31. Neharkar, V., \& Laware, S. (2013). Antibacterial and antifungal activity of hydro-alcoholic extract of Orthosiphon stamineus Benth. International Journal of Pharmaceutical Chemistry and Science, 2, 713-715. http://dx.doi.org/10.1080/13880209.2018.1462834

32. Owu, D., Nwokocha, C., Obembe, A., Essien, A., Ikpi, D., \& Osim, E. (2012). Effect of Gongronema latifolium ethanol leaf extract on gastric acid secretion and cytoprotection in streptozotocin-induced diabetic rats. West Indian medicine Journal, 61(9), 112-119.

33. Portillo, A., Vila, R., Freixa, B., Adzet, T. \& Canigueral, S. (2001). Antifungal activity of Paraguayan plants used in traditional medicine. Journal of Ethnopharmacology, 76(1), 93-98. https://doi.org/10.1016/s0378-8741(01)00214-8

34. Rajeswari, G., Murugan, M., \& Mohan, V.R. (2012). GC-MS Analysis of Bioactive Components of Hugonia Mystax L. (Linaceae). Research Journal of Pharmaceutical and Bio Chemical Science 3(4), 301-308. ISSN NO- 2230 - <background-color:\#D279AA;>7885</background-color:\#D279AA;>.

35. Rao, H., Lai, P. \& Gao, Y. (2017). Chemical composition, antibacterial activity, and synergistic effects with conventional antibiotics and nitric oxide production inhibitory activity of essential oil from Geophila repens. Molecules. 22(9), 1591. https://doi.org/10.3390/molecules22091561

36. Reeve, A. (1997). In vitro and in vivo antioxidant activities of aqueous extract of Strychonos henningsii. West Indian medicine Journal, 61(9), 112-119.

37. Robbrecht, E., \& Manen, J. (2006). The major evolutionary lineages of the coffee family (Rubiaceae, angiosperms). A new classification in two subfamilies, Cinchonoideae and Rubioideae. Systematics and Geography of Plants. 76:85-146.

38. Roessner, V., \& Sabine, M. (2011). Advances in Neurochemistry and Neuropharmacology of Tourette syndrome. International review of neurobiology, 281349.

39. Sales-Campos, H, Souza PR, Peghini BC, da- Silva, J.S., \& Cardoso, C.R. (2013). An overview of the modulatory effects of oleic acid. Mini Reviews in Medicinal Chemistry, 13 (2), 201-210. PMID: 23278117.

40. Sartoratto, A., Machado, A.L.M., Delarmelina, C., Figueira, G.M., Duarte, M.C.T., \& Rehder, V.L.G. (2004). Composition and antimicrobial activity of essential oils from aromatic plants used in Brazil. Brazilian Journal of Microbiology. 35, 275-80. https://doi.org/10.1590/S1517-83822004000300001

41. Sofowora, A. (1993). Medicinal Plants and Traditional Medicinal in Africa. 2nd Ed. Sunshine House, Ibadan, Nigeria: Spectrum Books Ltd, Screening Plants for Bioactive Agents; pp. 134-156.

42. Tan, M., Zhou, L., Huang, Y., Hao, X., \&Wang, J. (2008). Antimicrobial activity of globulol isolated from the fruits of eucalyptus globulus Labill. Natural Products Research, 22, 569-575. http://dx.doi.org/10.1080/14786410701592745

43. Vijayan, C., Adersh, M. \& Reji, S.R. (2013). Screening biological activities of Orthosiphon aristatus. International Journal of Advanced Research. 5, 594600. ISSN- 0975-1491

44. Vinothkumar, P., Sivaraj, A., Ahmed, K.S.Z., Sivamani, P., Devi, K. \& Senthilkumar, B. (2010). Evaluation of antibacterial activities of Andrographis paniculata leaf extract against gram negative and gram positive species by in vitro methods. Journal of Pharmacological Research, 3, $1513-1515$.

45. Wink, M. (2012). Medicinal plants: a source of anti-parasitic secondary metabolites. Molecules, 17, 12771-91. https://doi.org/10.3390/molecules171112771

46. Winstanley, T.G., Limb, D.L., Eggenton, R., \& Hancock, F. (1997). Ten year survey of the antimicrobial susceptibility of urinary tract isolates in the U K: The Microbased Project. Journal of Antimicrobial Chemotherapy, 40, 591-594.

47. Zeinab, B., Buthaina, J., \& Rafik, K. (2020). Resistance of Gram negative bacteria to current antibacterial agaents and approaches to resolve it. Molecule. 25(6), 1340. https://dx.doi.org/10.3390\%2Fmolecules25061340

\section{Figures}



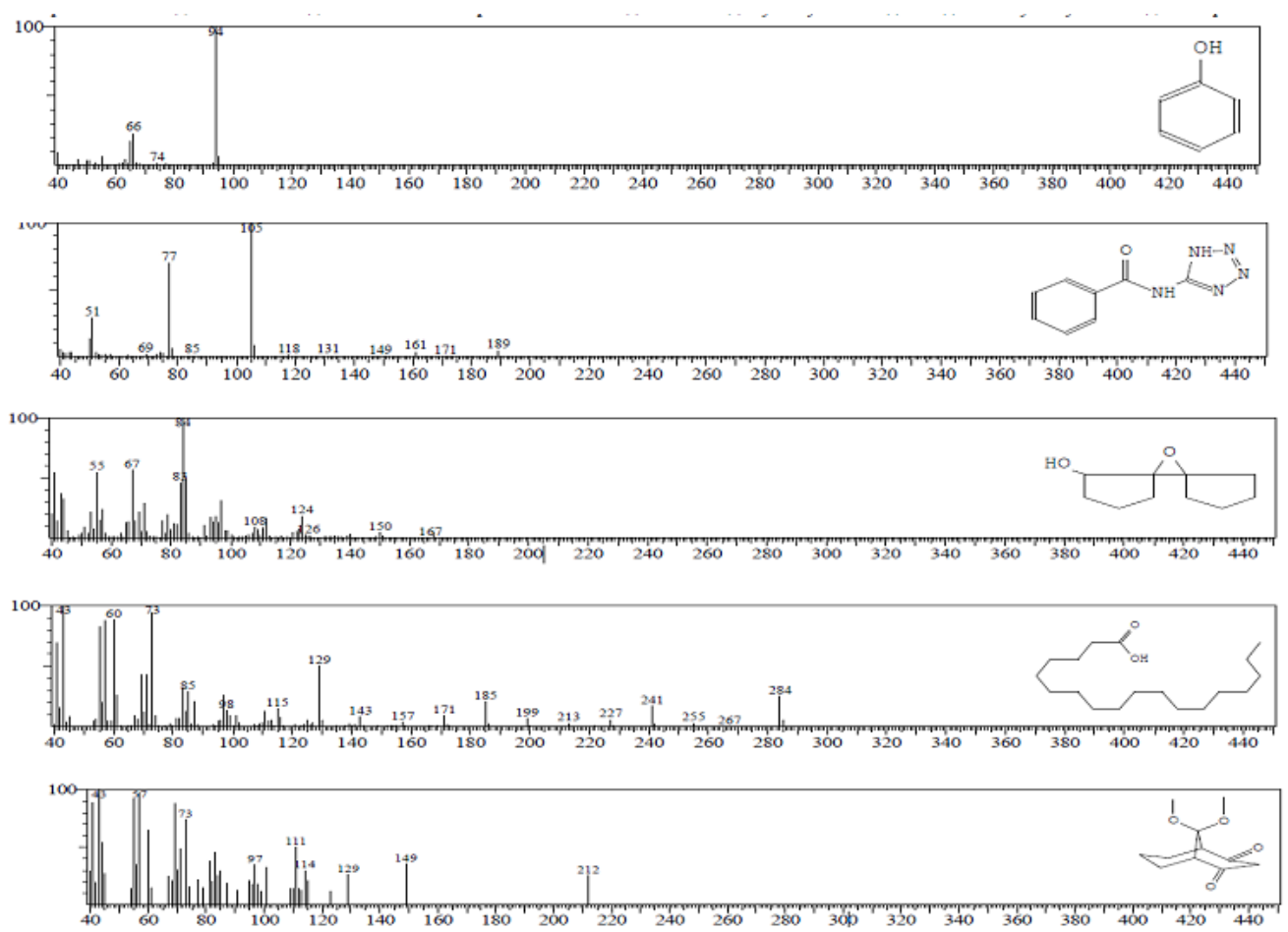

\section{Figure 1}

Mass spectra of some of the identified phytocompounds(phenol, N-(1H-Tetraazol-5-yl)benzamide, 11-0xa-dispiro, Hydrofol Acid, Dimethoxybicyclo, respectively). 